\title{
Glutathione Peroxidase Activity in the Blood of Tunas and Marlins ${ }^{\dagger}$
}

\author{
Norihisa Kai, ${ }^{* 1}$ Tomohide Tsuda, ${ }^{* 2}$ Tadashi Sakai, ${ }^{* 2}$ Hisashi Murata, ${ }^{* 2}$ \\ Moritsugu Hamada, ${ }^{* 1}$ Yasuhiro Tanoue, ${ }^{* 1}$ and Takeshi Nagai ${ }^{* 1}$ \\ ${ }^{{ }^{*}}$ Department of Food Science and Technology, National Fisheries University, \\ Nagata-Honmachi, Shimonoseki 759-65, Japan \\ ${ }^{* 2}$ Faculty of Agriculture, Miyazaki University, Gakuen-Kobanadai-nishi, \\ Miyazaki 889-21, Japan
}

(Received February 3, 1995)

\begin{abstract}
The glutathione peroxidase activity (GHS- $P_{\mathrm{x}}$ ) in eleven blood specimens of two species of tuna, i.e., nine individuals of yellow fin tuna Thunnus albacares and two individuals of big-eyed tuna Thunnus obesus, and in seven blood specimens of four species of marlin, i.e., three individuals of striped marlin Tetrapturus audax, two individuals of blue marlin Makaira mazara, one individual of swordfish Xiphias gladius and one individual of sailfish Istipohorus platyterus, are presented in relation to the distribution of selenium and mercury.

GSH-P $P_{x}$ in the blood of tunas was high compared with that of marlins, as in the cases of the selenium and mercury concentrations. In both species, GSH- $\mathrm{P}_{\mathrm{x}}$ did not significantly correlate with the concentration of the low oxidation state of selenium. On the other hand, GSH-P $\mathrm{P}_{\mathrm{x}}$ correlated netatively with the total mercury concentration in the case of marlins while there was no correlation in the case of tunas. These findings may suggest that since there are few protein-containing selenohydryl groups with mercury as organic selenium in the blood of marlins, GSH-P $\mathrm{P}_{\mathrm{x}}$ tends to drastically decrease with mercury accumulation.
\end{abstract}

Key words: blood, GSH- $\mathrm{P}_{\mathrm{x}}$, selenium, mercury

It is well known that selenium decomposes peroxides in the body as glutathione peroxidase (EC 1.11.1.9), and also counteracts the toxicity of heavy metals such as mercury. We have reported the relationship between selenium and marcuty in fish blood in which an antagonistic effect of selenium on the toxicity of heavy metals was clearly observed..$^{1-4)}$ As a result, it was found that there was a laege amount of selenium especially in the blood of tunas,,$^{1-3)}$ and moreover, the low oxidation state of selenium might be closely related to the detoxification of mercury in fish blood. ${ }^{4)}$ However, it was still unclear whether the low oxidation state of selenium, mainly organic selenium, exists as a constituent of glutathione peroxidase or the proteincontaining selenohydryl group, because glutathione peroxidase activity (abbreviated as GSH- $\mathbf{P}_{\mathrm{x}}$ ) on pelagic fish such as tuna and marlin has never been measured.

Therefore, as part of a series of studies on mercury and selenium in fish blood, we present here GSH-P $P_{x}$ in the blood of tunas and marlins, and also discuss the activity in relation to the distribution of selenium, especially the low oxidation state of selenium, and mercuty.

\section{Materials and Methods}

\section{Materials}

Eleven blood specimens of two species of tuna, i.e., nine individuals of yellow fin tuna Thunnus albacares and two individuals of big-eyed tuna Thunnus obesus, and in seven blood specimens of four species of marlin, i.e., three individuals of striped marlin Tetrapturus audax, two individuals of blue marlin Makaira mazara, one individual of swordfish Xiphias gladius and one individual of sailfish Istiophorus platyterus, were used in this study. Each individual was captured in the Bay of Bengal in May 1990, in the southwestern Pacific Ocean in December 1990 and in the South Pacific Ocean in May 1991.

The fork length of tunas and marlins are shown in Tables 1 and 2, respectively.

The blood was taken from the heart using a syringe and stored at $-40^{\circ} \mathrm{C}$ until analysis.

\section{Measurement of GSH-P}

GSH-P $\mathrm{P}_{\mathrm{x}}$ in the blood was assayed by the coupled test procedure using glutathione reductase-reduced nicotineamide dinucleotide phosphate (abbreviated as NADPH), and $t$-butyl hydroperoxide was used as a substrate. ${ }^{5,6)}$ One enzyme unit (abbreviated as $1 \mathrm{U}$ ) was then defined as the enzyme content oxidizing $1 \mathrm{nmol}$ of NADPH per minute. Using the hemoglobin values found for hemolysates, the GSH-P ${ }_{x}$ results were finally expressed as $\mathrm{U} / \mathrm{mg}$ hemoglobin (abbreviated as $\mathrm{U} / \mathrm{mg} \mathrm{Hb}$ ).

\section{Determination of Selenium and Mercury}

Total selenium (-II, 0, IV, and VI as oxidation number) and selenium ( $-\mathrm{II}, 0$, and IV as oxidation number) concentrations (abbreviated as T-Se and $\mathrm{Se}(-\mathrm{II}, 0$, IV), respectively) in each specimen were measured by means of gas chromatography with an electron capture de- 
Table 1. Analytical data from the blood of tunas

\begin{tabular}{|c|c|c|c|c|c|c|}
\hline Exp. Fish & $\underset{(\mathrm{cm})}{\mathrm{F} . \mathrm{L}^{*}}$ & $\begin{array}{c}\mathrm{Se}(-\mathrm{II}, 0, \mathrm{IV}) \\
(\mu \mathrm{g} / \mathrm{g})\end{array}$ & $\begin{array}{l}\mathrm{Se}(\mathrm{VI}) \\
(\mu \mathrm{g} / \mathrm{g})\end{array}$ & $\begin{array}{c}\mathrm{T}-\mathrm{Se} \\
(\mu \mathrm{g} / \mathrm{g})\end{array}$ & $\begin{array}{c}\mathrm{T}-\mathrm{Hg} \\
(\mu \mathrm{g} / \mathrm{g})\end{array}$ & $\begin{array}{c}\mathrm{GSH}-\mathrm{P}_{\mathrm{x}} \\
(\mathrm{U} / \mathrm{mg} \mathrm{Hb})\end{array}$ \\
\hline \multirow{9}{*}{$\begin{array}{l}\text { Yellow fin } \\
\text { tuna }\end{array}$} & 95.0 & $12.36_{2}$ & 0.32 & $12.69_{1}$ & $0.01_{2}$ & 26.5 \\
\hline & 99.0 & $21.71_{7}$ & $9.76_{4}$ & $31.48_{4}$ & $0.01_{0}$ & 20.0 \\
\hline & 121.0 & $18.31_{6}$ & $1.63_{2}$ & $19.94_{8}$ & 0.009 & 15.4 \\
\hline & 123.0 & $22.40_{7}$ & 6.073 & $28.48_{0}$ & $0.04_{6}$ & 16.2 \\
\hline & 123.0 & $15.66_{5}$ & $3.54_{5}$ & $19.21_{0}$ & $0.01_{5}$ & 23.7 \\
\hline & 133.0 & $38.66_{3}$ & $0.12_{0}$ & $38.78_{3}$ & $0.01_{9}$ & 20.7 \\
\hline & 133.0 & $16.76_{1}$ & $2.05_{6}$ & $18.81_{7}$ & $0.01_{2}$ & 24.9 \\
\hline & 151.0 & $17.59_{8}$ & $2.24_{5}$ & $19.84_{3}$ & $0.04_{7}$ & 18.7 \\
\hline & 155.0 & $17.45_{9}$ & $2.11_{7}$ & $19.57_{6}$ & $0.03_{3}$ & 24.9 \\
\hline $\begin{array}{l}\text { Big-eyed } \\
\text { tuna }\end{array}$ & $\begin{array}{l}109.0 \\
143.0\end{array}$ & $\begin{array}{l}17.33_{4} \\
27.98_{5}\end{array}$ & $\begin{array}{l}2.072 \\
8.92_{9}\end{array}$ & $\begin{array}{l}19.40_{6} \\
36.91_{4}\end{array}$ & $\begin{array}{l}0.25_{8} \\
0.21_{5}\end{array}$ & $\begin{array}{l}17.7 \\
25.0\end{array}$ \\
\hline Total Mean & 125.9 & $20.57_{0}$ & $3.53_{5}$ & $24.10_{4}$ & $0.06_{1}$ & 21.2 \\
\hline
\end{tabular}

* Fork Length.

Table 2. Analytical data from the blood of marlins

\begin{tabular}{|c|c|c|c|c|c|c|}
\hline Exp. Fish & $\begin{array}{c}\text { F. L. } \\
(\mathrm{cm})\end{array}$ & $\begin{array}{c}\mathrm{Se}(-\mathrm{II}, 0, \mathrm{IV}) \\
(\mu \mathrm{g} / \mathrm{g})\end{array}$ & $\begin{array}{l}\text { Se (VI) } \\
(\mu \mathrm{g} / \mathrm{g})\end{array}$ & $\begin{array}{c}\mathrm{T}-\mathrm{Se} \\
(\mu \mathrm{g} / \mathrm{g})\end{array}$ & $\begin{array}{c}\mathrm{T}-\mathrm{Hg} \\
(\mu \mathrm{g} / \mathrm{g})\end{array}$ & $\begin{array}{c}\text { GSH-P } \\
\text { (U/mg Hb) }\end{array}$ \\
\hline $\begin{array}{l}\text { Striped } \\
\text { marlin }\end{array}$ & $\begin{array}{l}134.0 \\
150.0 \\
159.0\end{array}$ & $\begin{array}{l}0.67_{2} \\
0.97_{1} \\
0.63_{1}\end{array}$ & $\begin{array}{l}0.18_{8} \\
0.04_{1} \\
0.11_{1}\end{array}$ & $\begin{array}{l}0.86_{3} \\
1.01_{8} \\
0.74_{2}\end{array}$ & $\begin{array}{c}0.01_{2} \\
- \\
0.00_{7}\end{array}$ & $\begin{array}{l}15.1 \\
16.6 \\
14.8\end{array}$ \\
\hline Swordfish & 75.0 & $1.67_{0}$ & $0.07_{4}$ & $1.74_{4}$ & $0.00_{1}$ & 17.3 \\
\hline $\begin{array}{l}\text { Blue } \\
\text { marlin }\end{array}$ & $\begin{array}{l}159.0 \\
183.0\end{array}$ & $\begin{array}{l}0.93_{1} \\
1.53_{6}\end{array}$ & $\begin{array}{l}0.79_{6} \\
0.22_{8}\end{array}$ & $\begin{array}{l}1.72_{7} \\
1.76_{4}\end{array}$ & $\begin{array}{l}0.02_{6} \\
0.09_{6}\end{array}$ & $\begin{array}{r}10.7 \\
9.7\end{array}$ \\
\hline Sailfish & 192.0 & $1.05_{1}$ & $0.04_{9}$ & $1.10_{0}$ & $0.01_{3}$ & 10.7 \\
\hline Total Mean & 150.3 & $1.06_{6}$ & $0.21_{3}$ & $1.28_{0}$ & $0.02_{6}$ & 13.6 \\
\hline
\end{tabular}

* Fork Length.

tector. ${ }^{7,8)}$ The selenium (VI) concentration was estimated by the difference between T-Se and $\mathrm{Se}(-\mathrm{II}, 0, \mathrm{IV})$, and abbreviated as $\mathrm{Se}$ (VI).

Total mercuty concentration in each specimen was also measured using flameless atomic absorption spectrometry, and abbreviated as $\mathrm{T}-\mathrm{Hg} .{ }^{9}$

\section{Results and Discussion}

Analytical data of $\mathrm{Se}(-\mathrm{II}, 0, \mathrm{IV}), \mathrm{Se}(\mathrm{VI}), \mathrm{T}-\mathrm{Se}, \mathrm{T}-\mathrm{Hg}$, and GSH-P $P_{x}$ in the blood of tunas and marlins are shown in Tables 1 and 2, respectively. The number of analytical samples for $\mathrm{T}-\mathrm{Hg}$ was six in the case of marlin.

Each mean value of $\mathrm{Se}(-\mathrm{II}, 0$, IV), Se(VI), T-Se, T-Hg, and GSH-P $P_{x}$ in the blood of tunas was significantly high compared with that in merlins. GSH-P $\mathrm{P}_{\mathrm{x}}$ in the blood of both species was higher than that in yellow tail Seriola quinqueradiata $(11.9 \mathrm{U} / \mathrm{mg} \mathrm{Hb}$ as mean value of twelve specimens) (unpublished). We previously reported that selenium and marcury levels in the blood of tunas were significantly high compared with those in marline ${ }^{1-4)}$ Therefore, the difference in GSH- $\mathrm{P}_{\mathrm{x}}$ may be due to the distribution of both elements, beause it is postulated that there is little difference in the peroxide content between both species at about the same trophic level of the marine ecosystem.

Here, the chemical form of the constituent of Se(VI) will be selenate, and that of $\operatorname{Se}(-\mathrm{II}, 0$, IV) will mainly be organic selenium, selenide and selenite. Moreover, the chemical state of the organic selenium is considered to be the protein-containing selenohydryl group (-SeH), that with mercury $(-\mathrm{SeHg})$, and glutathione peroxidase. We then clarified the contribution of $\mathrm{Se}(-\mathrm{II}, 0, \mathrm{IV})$ to $\mathrm{T}-\mathrm{Se}$ in the blood of tunas and marlins. As a results, significant positive correlations were observed $\left(r_{0}=0.91\right.$ and 0.80 in tunas and in marlins, respectively), and $\mathrm{Se}(-\mathrm{II}, 0, \mathrm{VI})$ was dominant in both species. In general, in sea water, especially in surface waters, selenate is dominant.$^{107}$ This finding in fish blood may suggest that a low oxidation state of selenium would be dominant in fish, especially at a high trophic level, since selenium species in plankton are considered to be mainly selenite and organic selenium (unpublished).

In the case of rats, it has been reported that after the administration of selenium into the body as selenide, selenium is finally reduced to selenide, which reacts with some heavy metals and detoxifies those metals in the presence of glutathione. ${ }^{11}$ A similar mechanism for the metabolism of selenium in rats is also speculated for fish. Therefore, in order to clarify the contribution of $\mathrm{Se}(-\mathrm{II}, 0, \mathrm{IV})$ to GSH-P $P_{x}$ in the blood of tunas and marlins, the relationships between $\mathrm{Se}(-\mathrm{II}, 0, \mathrm{IV})$ and GHS- $\mathrm{P}_{\mathrm{x}}$ are shown in Figs. 1 and 2, respectively. No correlation on the logarithmic scale was found between $\mathrm{Se}(-\mathrm{II}, 0, \mathrm{IV})$ and GSH-P $P_{x}$ in both species. Moreover, the relationships between $\mathrm{T}-\mathrm{Hg}$ and GSH-P $\mathrm{P}_{\mathrm{x}}$ are shown in Figs. 3 and 4. As the regression curve shows, there was a negative correlation $\left(r_{0}=-0.84\right)$ on the logarithmic scale between $\mathrm{T}-\mathrm{Hg}$ and GSH-P $P_{x}$ only in the case of marlins.

Iwate et al. demonstrated that the reaction of mercury with selenium in the presence of glutathione leads to the formation of mercuric selenide as a detoxified substance and generates the oxidized form of glutathione. ${ }^{12)}$ The

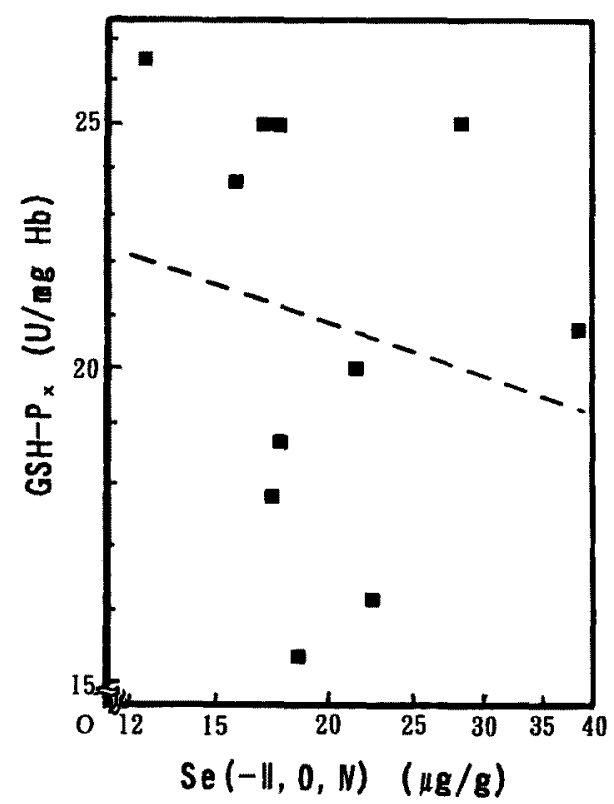

Fig. 1. Relationship between $\mathrm{Se}(-\mathrm{II}, 0, \mathrm{IV})$ and GSH-P $\mathrm{P}_{\mathbf{x}}$ in the blood of tunas.

A broken line in the figure shows a regression curve without correlation. 


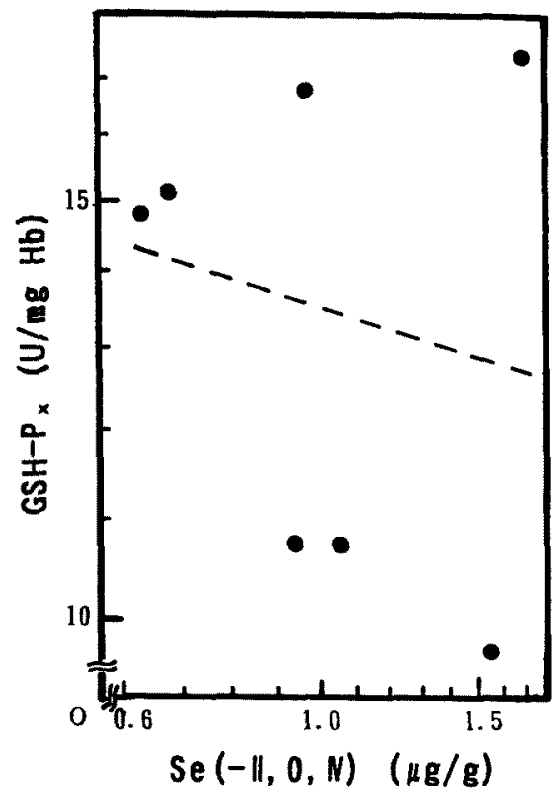

Fig. 2. Relationship between $\mathrm{Se}(-\mathrm{II}, 0, \mathrm{IV})$ and GSH-P $\mathbf{P}_{\mathrm{x}}$ in the blood of marlins.

The meaning of a broken line in the figure is the same as that in Fig. 1.

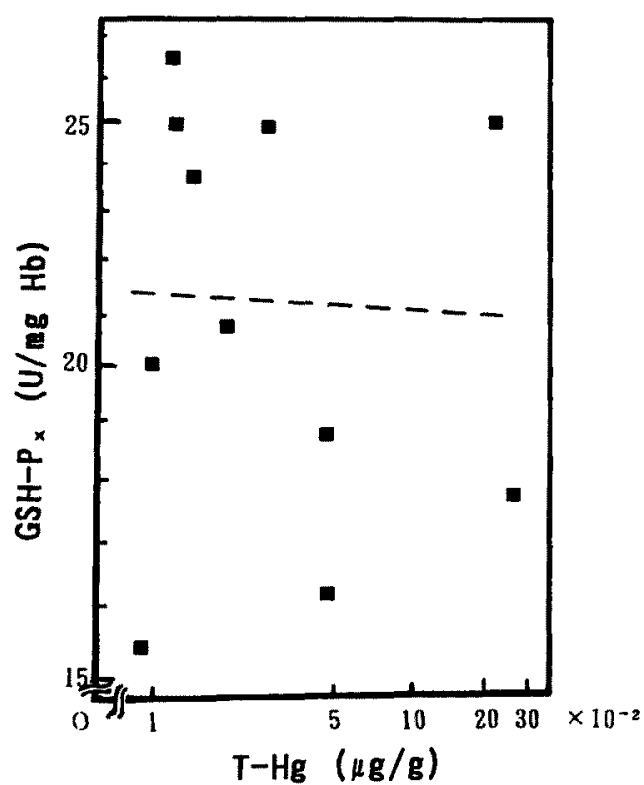

Fig. 3. Relationship between $\mathrm{T}-\mathrm{Hg}$ and $\mathrm{GSH}-\mathrm{P}_{\mathrm{x}}$ in the blood of tunas. The meaning of a broken line in the figure is the same as that in Fig. 2.

decrease of glutathione, which is equivalent to oxidized nicotineamide dinucleotide phosphate, then results in the depression of GSH-P $x$ with mercury accumulation in the case of marlins.

Therefore, these findings suggest that there is a large amount of protein-containing selenohydryl groups with or without mercury or of selenite, in addition to glutathione peroxidase and mercuric selenide in the blood of tunas, while there are few protein-containing selenohydryl groups with mercury except for the protein-containing

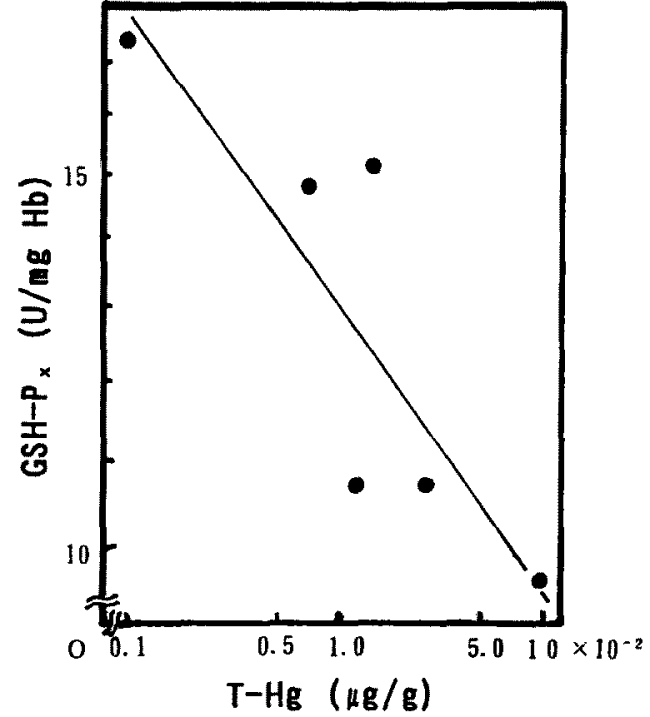

Fig. 4. Relationship between $\mathrm{T}-\mathrm{Hg}$ and GSH-P $\mathrm{P}_{x}$ in the blood of marlins.

A solid line in the figure shows a regression curve with a significant correlation at a significance level of $5 \%$.

selenohydryl group, glutathione peroxidase, and mercuric selenide in the blood of marlins. The difference in selenium and mercury distributions between both species may be due to the rate of metabolism of both elements in the fish body, although both tunas and marlins are pelagic fish at about the same high trophic level in the marine ecosystem. However, since few specimens were used in this study, further studies will be needed to verify out speculations.

\section{References}

1) N. Kai, T. Ueda, Y. Takeda, and A. Kataoka: The levels of mercury and selenium in the blood of tuna. Nippon Suisan Gakkaishi, 54 1981-1985 (1988)

2) N. Kai, T. Ueda, Y. Takeda, and K. Nagatomo: On mercury and selenium in fish blood-II. The difference in levels of mercury and selenium in the blood of tuna between two different fishing locations, and between two species. J. Shimonoseki Univ. Fish., 38, 710 (1989).

3) N. Kai, T. Ueda, and K. Nagatomo: On mercury and selenium in fish blood-III. Comparison between blood and muscle or several organs in the levels of mercury and selenium in big-eye. $J$. Shimonoseki Univ. Fish., 38, 11-16 (1989).

4) N. Kai, T. Ueda, and Y. Takeda: The state of oxidation and its distrubution of selenium in the blood of tuna and marlins. Nippon Suisan Gakkaishi, 58, 1883-1886 (1992).

5) P. Cikryt, S. Feuerstein, and A. Wendel: Selenium- and non-selenium-dependent glutathione peroxidase in mouse liver. Biochem. Pharmacol., 31, 2873-2877 (1982).

6) W. J. Blanchflower, D. A. Rice, and W. B. Davidson: Blood glutathione peroxidase-A method for measurement and the influence of storage, cyanide, and Drabkin's reagent on enzyme activity. Biol. Trace Element Res., 11, 89-100 (1986).

7) K. Tôei and Y. Shimoishi: Determination of ultramicro amounts of selenium by gas chromatography with electron-capture detection. Talanta, 28, 967-972 (1981).

8) H. Uchida, Y. Shimoishi, and K. Tôei: Rapid determination of trace amounts of selenium in biological samples by gas chromatography. Analyst, 106, 757-762 (1981). 
9) M. Takeda, Y. Inamasu, T. Tomita, M. Hamada, and H. Katsuura: On mercury and selenium contained in tuna fish tissues-I. Vanadium pentoxide-catalyzed wet digestion for the determination of total mercury in tuna tissues. J. Shimonoseki Univ. Fish., 23, 145-153 (1975)

10) Y. Nakaguchi, K. Hiraki, Y. Tamari, Y. Fukunaga, Y. Nishikawa, and $T$. Shigematsu: Fluorometric determination of inorganic selenium (IV), selenium (VI) and organic selenium in natural waters.
Anal. Sci., 1, 247-252 (1985).

11) R. A. Sunde and W. G. Hoekstra: Incorporation of selenium from selenite and selenocysteine into glutathione peroxidase in the isolated perfused rat liver. Biochem. Biophys. Res. Commun., 93, 11811186 (1980).

12) H. Iwata, T. Matsunaga, H. Kito, and M. Hayashi: Degradation of methylmercury by selenium. Life Sci., 31, 859-866 (1982). 